\title{
舫 New Disease Reports \\ First record of smut caused by Entyloma eschscholziae on California poppy in the United Kingdom
}

B. Henricot ${ }^{1 *}$, J. Scrace ${ }^{1}$ and B. Spooner ${ }^{2}$

\author{
${ }^{1}$ Plant Pathology, The Royal Horticultural Society (RHS), Wisley, Woking, Surrey, GU23 6QB, UK; ${ }^{2}$ Royal Botanic Gardens, \\ Kew, Richmond, Surrey TW9 $3 A E$, UK
}

*E-mail: beatricehenricot@rhs.org.uk

Received: 12 Feb 2013. Published: 17 Oct 2013. Keywords: Eschscholzia californica, basidiomycete, fungal disease

California poppy (Eschscholzia californica) is grown in UK gardens as an annual for its colourful display. In October 2012, diseased samples of California poppies (cv. Summer Sun) collected in a garden in Shropshire (West Midlands) were received at the advisory service at RHS Wisley. The plants were grown from seeds and about $80 \%$ of the plants were affected. Symptoms included white oval-shaped leaf spots surrounded by a dark border (Fig. 1). The spots were $1 \mathrm{~mm}$ in length or less on the lower and upper leaf surfaces and on the stems. The leaves became wilted and blackened. Microscopic examination revealed the presence of globose or polygonal hyaline to brown ustilospores measuring 8.3-14.8 x 7.2-12.8 $\mu \mathrm{m}$ (average $10.4 \times 8.4 \mu \mathrm{m}$ ), wall 2-layered and 0.4-1.5 $\mu \mathrm{m}$ thick (Fig. 2). Long, filiform, slightly bent basidiospores measuring 24-62 × $2 \mu \mathrm{m}$ (average $43.2 \times 2 \mu \mathrm{m}$ ) were observed. According to Vánky (pers. com.), these have been observed in the genus Entyloma and, after or without conjugation, can produce secondary or tertiary sporidia. Sporidia were also observed and these were hyaline, cylindrical, mostly curved, unicellular, rounded at one end and tapered at the other end. They measured 9.4-16.5 2-3.6 $\mu \mathrm{m}$ (average $13.9 \times 2.8 \mu \mathrm{m}$ ). The symptoms and the hyaline, densely aggregated spores embedded within the leaf tissue were characteristic of a smut fungus belonging to the genus Entyloma.

Morphological examination and host association of the fungus suggested it should be referred to Entyloma eschscholziae Harkness, the only species known from this host (Vánky, 2012). To obtain additional evidence, DNA was extracted from infected plant material using the Plant DNAeasy ${ }^{\mathrm{TM}}$ mini kit (Qiagen, Germany) according to the manufacturer's instructions The ITS region was amplified using ITS $1 \mathrm{~F}$ and ITS 4B primers (Gardes \& Bruns, 1993) and sequenced (GenBank Accession No. KC456226). The DNA sequence was $100 \%$ identical to an uncultured Basidiomycota detected in grassland soils in California (HM240159). The sequence was also closely related to Entyloma species. The closest match to DNA sequences determined to the species level within GenBank was with $E$. bidentis (coverage 84\%, 98\% identity, AY854963) and E. eryngii-plani (coverage 84\%, 98\% identity, AY081034). Sequences of $E$. eschscholziae were not available in GenBank. In general, the molecular work carried out by Begerow et al. (2002) supported a species concept for the genus Entyloma based on host specificity. Altogether, based on the morphological characteristics, sequencing of the ITS and host specificity, the smut was confirmed as Entyloma eschscholziae (Harkness, 1884; Vánky 2012; Farr \& Rossman, 2013). The original description of this species does not include an anamorph (Harkness, 1884; Vánky 2012) and although conidia were observed by Savile, (1946), these were not described. A voucher specimen was deposited at the Royal Botanic Gardens, Kew, UK (K(M)179304). A subsequent collection on this host from the Royal Botanic Gardens, Kew was obtained by A.M. Ainsworth on 22 Oct. 2012, accessed as K(M)179357. This is the first report of Entyloma eschscholziae causing smut in the UK and also in Europe. Until now, this disease has only been reported in California and New Zealand (Farr \& Rossman, 2013).

\section{References}

Begerow D, Lutz M, Oberwinkler F, 2002. Implications of molecular characters for the phylogeny of the genus Entyloma. Mycological Research 106, 1392-1399. [http://dx.doi.org/10.1017/S0953756202006962]

Farr DF, Rossman AY, 2013. Fungal Databases, Systematic Mycology and Microbiology Laboratory, ARS, USDA. Retrieved January 31, 2013, from http://nt.ars-grin.gov/fungaldatabases/

Gardes M, Bruns TD, 1993. ITS primers with enhanced specificity for basidiomycetes - application to the identification of mycorrhizae and rusts. Molecular Ecology 2, 113-118.

[http://dx.doi.org/10.1111/j.1365-294X.1993.tb00005.x]

Harkness HW, 1884. New species of California fungi. Bulletin of California Academy of Sciences 1, 29-47.

Savile DBO, 1946. Entyloma fuscum and related smuts attacking Papaveraceae. Canadian Journal of Research 24, 109-114.

Vánky K, 2012. Smut fungi of the world. St. Paul, MN, USA: APS Press.

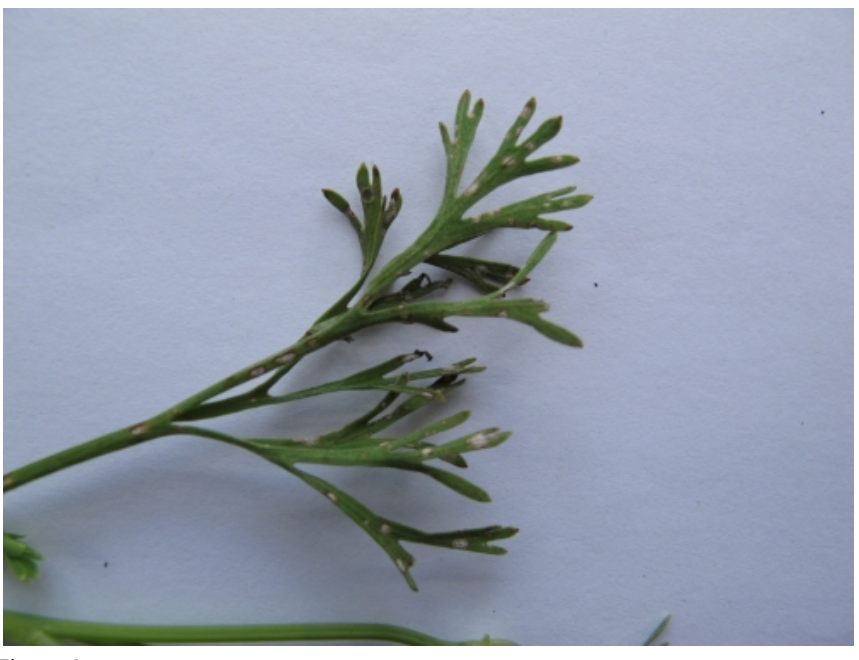

Figure 1

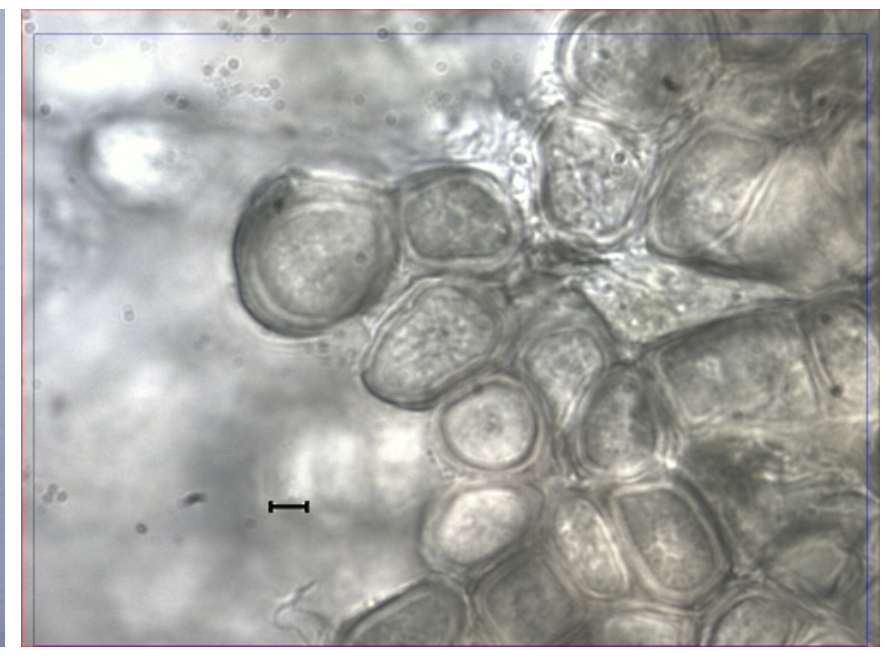

Figure 2

To cite this report: Henricot B, Scrace J, Spooner B, 2013. First record of smut caused by Entyloma eschscholziae on California poppy in the United Kingdom. New Disease Reports 28, 10. [http://dx.doi.org/10.5197/j.2044-0588.2013.028.010] 